\title{
KEBERADAAN BADAN USAHA MILIK DESA (BUMDES) SEBAGAI PENGUATAN EKONOMI DESA ABIANTUWUNG
}

\author{
Hillalliatun Febryani, Rika Nurmalia, I Made Indra Lesmana, Ni Kadek Wiwik \\ Ulantari, Desak Putu Yuliani Puspa Dewi, Nina Rizky \\ Jurusan Akuntansi, Universitas Pendidikan Ganesha, Singaraja, Bali, Indonesia
}

\begin{abstract}
Abstrak
Penelitian ini bertujuan untuk mengungkap bagaimana Pengelolaan Badan Usaha Milik Desa pada Desa Abiantuwung dan bagaimana Perkembangan dan Peningkatan Perekonomian Desa AbianTuwung dengan keberadaan Badan Usaha Milik Desa atau BUMDES. Penelitian ini merupakan jenis penelitian kualitiatif dengan teknik pengumpulan data berupa wawancara dan dokumentasi. Hasil penelitian menunjukkan bahwa 1) BUMDES Desa Abiantuwung telah berhasil memberi dampak yang positif bagi peningkatan perekonomian desa dan kesejahteraan masyaraka, BUMDES Desa Abiantuwung yang berdampak terhadap tingkat masyarakat konsumtif ini, semakin berkurang, dan masyarakat produktif mulai meningkat; 2) Pengelolaan Desa Abiantuwung pada BUMDES sangat tertata dengan berpacu pada peraturan yang sudah ditetapkan oleh Pemerintah; serta 3) BUMDES Desa Abiantuwung walaupun belum maksimal dalam menjalankan unit-unit usahanya.
\end{abstract}

Kata kunci: BUMDes; penguatan ekonomi; desa Abiantuwung

\begin{abstract}
This study aims to reveal how the Management of Village-Owned Enterprises in Abiantuwung Village and how the Development and Improvement of the Economy of AbianTuwung Village with the existence of Village-Owned Enterprises or BUMDES. This research is a type of qualitative research with data collection techniques such as interviews and documentation. The results showed that 1) BUMDES of Abiantuwung Village had succeeded in having a positive impact on improving the village economy and community welfare, BUMDES of Abiantuwung Village that had an impact on the level of this consumptive society, had diminished, and productive communities began to increase; 2) The management of Abiantuwung Village in BUMDES is highly organized with regard to regulations that have been established by the Government; and 3) BUMDES of Abiantuwung Village, although it is not yet optimal in running its business units.
\end{abstract}

Keyword : BUMDes; economic strengthening; Abiantuwung village

\section{Pendahuluan}

Pembangunan pada hakekatnya bertujuan membangun kemandirian, termasuk pembangunan pedesaan. Salah satu misi pemerintah adalah membangun daerah pedesaan yang dapat dicapai melalui pemberdayaan masyarakat untuk meningkatkan produktivitas dan keanekaragaman usaha pedesaan, membangun dan memperkuat institusi yang mendukung rantai produksi dan pemasaran, serta mengoptimalkan sumber daya sebagai dasar pertumbuhan ekonomi pedesaan. Tujuannya, adalah untuk memberi peluang bagi kemampuan daerah dan pedesaan sebagai tulang punggung ekonomi regional dan nasional.

Kemajuan ekonomi nasional hanya akan tercapai jikaterdapat iklim perekonomian yang baik di tingkat provinsi. Kemajuan ekonomi di tingkat provinsi akan tercapai jika kabupaten memiliki kegiatan ekonomi yang baik. Kemajuan ekonomi sebuah kabupaten dapat tercapai karena adanya sumbang dari ekonomi pedesaan yang kuat berimbas pada kesejahteraan masyarakat luas. Hal ini akan menjamin penyelenggaraan pemerintahan yang baik untuk diterapkan di semua tingkat pembangunan dan keputusan berdasarkan kebutuhan nyata dari masyarakat. Pembangunan pedesaan merupakan salah satu cara dalam upaya mengentaskan kemiskinan di Indonesia.

Pengembangan basis ekonomi di pedesaan sudah semenjak lama dijalankan oleh pemerintah melalui berbagai program. Namun upaya itu belum memuaskan sebagaimana diinginkan bersama. Salah satu faktor yang paling dominan adalah intervensi pemerintah terlalu besar, akibatnya justru menghambat daya kreativitas dan inovasi masyarakat dessa dalam mengelola dan menjalankan mesin ekonomi di pedesaan. Sistem dan mekanisme 
kelembagaan ekonomi di pedesaan tidak berjalan efektif dan berimplikasi pada ketergantungan terhdapa bantuan pemerintah sehinggan memastikan semangat kemandirian.

Berdasarkan asumsi itulah maka sudah seharusnya eksistensi desa mendapatkan perhatian yang serius dari pemerintah pusat dengan lahirnya kebijakan-kebijakan terkait dengan pemberdayaan ekonomi yang dilakukan dengan cara menghimpun dan melembagakan kegiatan ekonomi masyarakat. Oleh karena itu pemerintah menerapkan pendekatan baru yang diharapkan mampu menstimulus dan menggerakkan roda perekonomian di pedesaan adalah melalui pendirian kelembagaan ekonomi yang dikelola sepenuhnya oleh masyarakat desa yaitu Badan Usaha Milik Desa (BUMDES) sebagai salah satu program andalan dalam meningkatkan kemandirian perekonomian desa.

BUMDES lahir sebagai suatu pendekatan baru dalam usaha peningkatan ekonomi desa berdasarkan kebutuhan dan potensi desa. Pengelolaan BUMDES sepenuhnya dilaksanakan oleh masyarakat desa, yaitu dari desa, oleh desa, dan untuk desa. Cara Kerja BUMDES adalah dengan jalan menampung kegiatan-kegiatan ekonomi masyarakat dalam sebuah bentuk kelembagaan atau badan usaha yang dikelola secara professional, namun tetap bersandar pada potensi asli desa. Hal ini dapat menjadikan usaha masyarakat lebih produktif dan efektif. Kedepan BUMDES akan berfungsi sebagai pilar kemandirian bangsa yang sekaligus menjadi lembaga yang menampung kegiatan ekonomi masyarakat yang berkembang menurut ciri khas desa dalam rangka meningkatkan kesejahteraan masyarakat desa.

Adapun salah satu desa yang termasuk dalam ciri khas BUMDES tersebut adalah Desa Abiantuwung, Kecamatan Kediri, Kabupaten Tabanan dimana desa ini merupakan desa yang sudah memiliki BUMDES dan telah berjalan mulai tahun 2015. Desa AbianTuwung merupakan desa yang dipilih oleh pemerintah untuk diberikan berpeluang berkembang menjadi masyarakat desa yang kreatif, inovatif, dan produktif. Seluruh kebutuhan dana bagi pengembangan Desa Abiantuwung diperoleh dari kebutuhan Badan Usaha Milik Desa (BUMDES) Abiantuwung. Seiring berjalannya waktu Desa Abiantuwung mulai mengalami perkembangan, oleh masyarakat, pembangunan daerah, dan tingkat produktif masyarakat meningkat. Untuk menjalankan hal tersebut Pemerintah Daerah AbianTuwung berpedoman pada Peraturan Daerah Kabupaten Tabanan Nomor 1 Tahun 2015 tentang Badan Usaha Milik Desa (BUMDES) yang menjadi acuan dalam pembentukan Badan Usaha Milik Desa yang ada di Tabanan.

Jauh sebelum adanya BUMDES di Desa Abiantuwung ini masyarakatnya masih sangat konsumtif. Masyarakat seakan bersaing satu sama lain untuk memenuhi keinginan dan gaya hidup yang seolah tidak ingin kalah antara yang satu dengan yang lainnya. Sehingga dengan kehidupan yang seperti itu semakin terlihat kesenjangan ekonomi yang semakin besar, karena kehidupan konsumtif yang tidak dibarengi dengan pendapatan yang memadai.

Desa abian tuwung ini termasuk desa dengan ekonomi yang kurang stabil karena tidak ada perkembangan yang terlihat signifikan dari usaha-usaha yang didirikan. Selain itu kondisi masyarakat konsumtif yang tidak ada keinginan melakukan perubahan juga menjadi pemicu utama ketidak stabilan perekonomian masyarakat.

Dari sekian banyak masyarakat yang konsumtif tentunya ada segelintir masyarakat yang memiliki kesadaran dan ingin mengubah hidupnya. Tak sedikit juga dari mereka yang ingin mulai membangun usaha, akan tetapi pada saat itu hanya LPD yang menjadi tempat masyarakat dalam mengambil kredit. Seperti yang telah diketahui berdasarkan survei yang telah dilakukan bahwa bunga yang diberikan LPD untuk kredit lumayan besar sehingga masyarakat masih berpikir ulang untuk meminjam kredit sebagai modal usaha. Jadi, dapat disimpulkan bahwa sebelum adanya BUMDES di daerah Abiantuwung perekonomiannya tidak stabil karena masyarakat yang bersifat konsumtif yang belum memiliki keinginan untuk merubah gaya hidup mereka. Selain itu pemicu ketidak stabilan perekonomian di desa ini adalah keinginan masyarakat yang muncul akan tetapi terbentur dengan keadaan kredit yang mempunyai bunga lumayan tinggi. 
Pembentukan BUMDES di Desa Abiantuwung ini memiliki tujuan utama untuk meningkatkan taraf hidup masyarakat miskin agar kesenjangan sosial di desa ini tidak bertambah besar, karena menurut survei yang telah dilakukan bahwa masih banyak jumlah KK di desa ini yang termasuk kategori masyarakat miskin yaitu sebesar $294 \mathrm{KK}$ dari total keseluruhan masyarakat abian tuwung yang berjumlah 2735 jiwa. Selain itu tujuan lain dari pembentukan BUMDES adalah untuk membentuk masyarakat yang produktif bukan masyarakat konsumtif yang menjadi gaya hidup masyarakat abian tuwung selama ini. Untuk mencapai tujuan tersebut banyak sekali hal yang telah dilakukan oleh pemerintah Desa Abiantuwung, salah satunya adalah dengan memberikan sosialisasi tentang kredit yang bersumber dari dana BUMDES untuk kredit produktif. Akan tetapi, pada kenyataannya sangatlah berbeda dengan apa yang diharapkan. Dengan adanya kredit produktif tersebut masyarakat malah memakai kredit tersebut untuk memenuhi gaya hidup konsumtif yang selama ini menjadi bagian hidup mereka, walaupun ada beberapa yang memang menggunakan kredit tersebut untuk ekonomi produktif yaitu dengan memanfaatkan dana kredit untuk membuka usaha.

Kami selaku penulis bermotivasi untuk melakukan penelitian di Desa Abiantuwung dengan menggunakan metode penelitian kualitatif dimana metode penelitian kualitatif merupakan penelitian tentang riset yang bersifat deskriptif dan cenderung menggunakan analisis, sehingga desa ini menurut kami sangat bagus untuk kami teliti dan mengetahui informasinya, dilihat dari kenyataannya desa ini mengalami perubahan setelah adanya BUMDES, dan sebelum adanya BUMDES. Begitupula dengan Perekonomian di Desa ini.

\section{Kerangka Pemikiran}

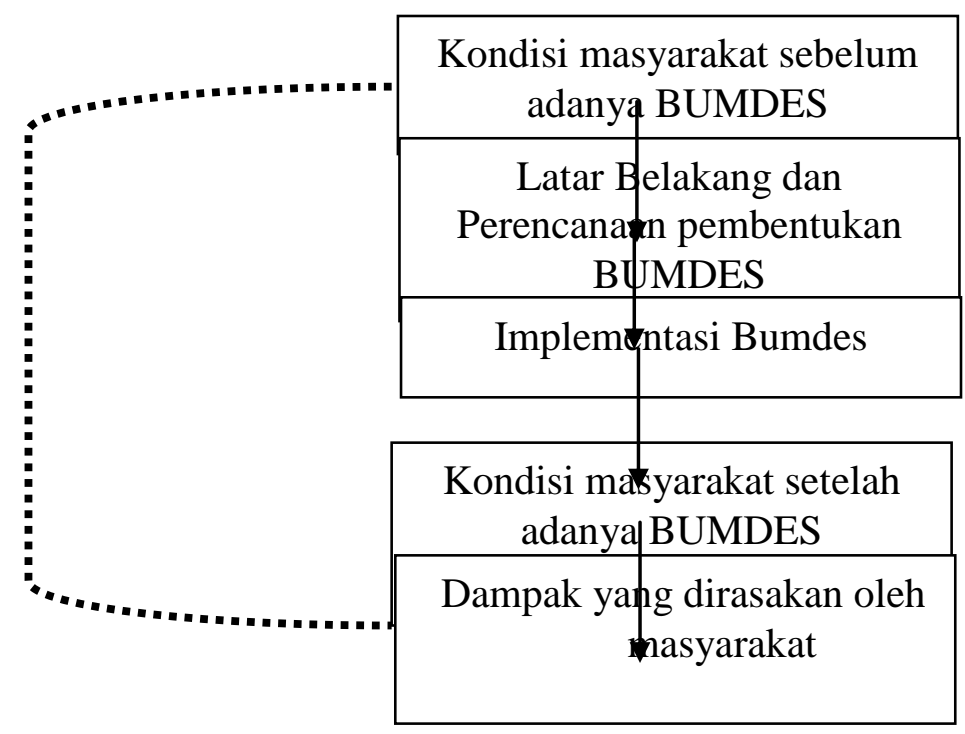

Berdasarkan latar belakang diatas, permasalahan yang dapat dirumuskan adalah bagaimana Pengelolaan Badan Usaha Milik Desa pada Desa Abiantuwung dan bagaimana Perkembangan dan Peningkatan Perekonomian Desa AbianTuwung dengan keberadaan Badan Usaha Milik Desa atau BUMDES.

\section{Pembahasan}

\subsection{Pengelolaan Badan Usaha Milik Desa pada Desa Abiantuwung \\ Pendirian dan Pengelolaan Badan Usaha Milik Desa (BUMDES) secara Umum}

Pembentukan Badan Usaha Milik Desa (BUMDES) bertujuan sebagai lokomotif pembangunan ekonomi lokal tingkat desa. Pembangunan ekonomi lokal desa ini didasarkan oleh kebutuhan, ptotensi, kapasitas desa, dan penyertaan modal dari pemerintah desa dalam bentuk pembiayaan dan kekayaan desa dengan tujuan akhirnya adalah meningkatkan taraf ekonomi mayarakat desa. Dasar pembentukan BUMDES sebagai lokomotif pembangunan di desa lebih dilatarbelakangi pada prakarsa pemerintah dan masyarakat 
desa dengan berdasarkan pada prinsip kooperatif, partisipatif, dan emansipatif dari masyarakat desa.

Di dalam Buku Panduan BUMDES yang diterbitkan oleh kementerian Pendidikan Nasional tahun 2007 dijelaskan secara terperinci bahwa ada beberpa tahapan dalam proses pendirian BUMDES. Selain itu juga dijelaskan mengenai cara dan syarat pendirian BUMDES yang terdiri atas:

1. Pendirian BUMDES berdasar pada Perda Kabupaten

2. Diatur berdasarkan Perdes

3. Satu Desa, hanya terdapat satu BUMDES

4. Pemkab memfasilitasi pendirian BUMDES

5. BUMDES dapat didirikan dalam bentuk Usaha Bersama atau bentuk lainnya, tetapu bukan Koperasi, PT, Badan Usaha Milik Desa, CV, UD, atau lembaga keuangan (BPR).

Dalam peraturan Menteri Desa No. 4/2015 pasal 5 juga menjelaskan mengenai proses pendirian BUMDES yang berbunyi "Pendirian BUMDES sebagaiman dimaksud dala pasal 4 disepakati melalui Musyawarah Desa, sebagaimana diatur dalam peraturan Menteri Desa, Pembangunan Daerah Tertinggal, dan Transmigrasi tentang Pedoman Tata tertib dan Mekanisme Pengambilan Keputusan Musyawarah Desa". Musyawarah Desa yang dimaksud pada pasal tersebut membahas beberapa halyang terkait dengan proses pendirian desa. Inti pokok bahasannya adalah:

1. Pendirian BUMDES Desa sesuai dengan Kondisi ekonomi dan social budaya mayarakat.

2. Organisasi pengelola BUMDES

3. Modal Usaha BUMDES

4. Anggaran Dasar dan Anggaran Rumah Tangga BUMDES.

Empat Inti pokok bahasan inilah yang kemudian menjadi darsar pedoman bagi Pemerintah Desa dan Badan Permusyawaratan Desa untuk menetapkan Peraturan Desa tentang Pendirian BUMDES.

Selanjutnya mengenai pengelolaan BUMDES, Permendesa No. 4/2015 mengatur secara jelas dan detail mengenai pengelolaan teknis pelaksanaan BUMDES disertai dengan peran dan fungsi dari masing-masing perangkat BUMDES, memang isi Permendesa No.4/2015 ini berlaku umum, artinya tetap saja dalam pelaksanaan di daerah harus ada penyesuaian yang kemudian diatur oleh peraturan Bupati/Walikota sesuai dengan keadaan alam, lingkungan, dan budaya setempat.

Pengelolaan BUMDES harus dikelola secara professional dan mandiri sehingga diperlukan orang-orang yang memiliki kompetensi untuk mengelolanya. Perekrutan pegawai ataupun manajer dan selevel harus disesuaikan dengan standar yang sudah ditetapkan dari AD/ART BUMDES. Sebagai sebuah lembaga yang juga diwajibkan mendapat profit, tentunya ada mekanisme yang harus ditaati oleh pengelola BUMDES dalam melakukan kerjasama dengan pihak lain. Misalnya kegiatan yang bersifat lintas desa perlu dilakukan koordinasi dan kerjasama antar pemerintah Desa dalam Pemanfaatan sumber-sumber ekonomi, misalnya sumber air bagi air minum. Dalam melakukan Kerjasama dengan pihak ketiga oleh pengelola harus dengan konsultasi dan persetujuan Dewan Komisaris BUMDES. Dalam kegiatan harian pengelola harus mengacu pada tata aturan yang sudah disepkati bersama sebagaimana yang telah tertuang dalam AD/ART BUMDES, serta sesuai prinsipprinsip tata kelola BUMDES.

Satu hal yang penting dalam pengelolaan BUMDES yakni dalam proses pengelolaan BUMDES amat dibutuhkan suatu pengelolaan dan pelaporan yang transparan bagi pemerintah dan masyarakat. Artinya dasar pengelolaan harus serba transparan dan terbuku sehingga ada mekanisme chek and balance baik oleh pemerintahan desa maupun masyarakat. Untuk langkah ke depan sangat diperlukan buah penyusunan RencanaRencana pengembangan usaha. Contoh yang dapat di ambil, untuk penjualan produkproduk yang dipengaruhi oleh musim, seperti penjualan pakaian, sandal, sepatu, dan sejenisnya penting untuk selalu memperhatikan perubahan mode, sebab jika tidak dilakukan vesar kemungkinan produknya tidak diminati oleh pasar, untuk itu diperlukan inovasi baru atau selalu mewaspadai perubahan dan perkembangan yang terjadi di masyarakat. 


\section{i. Pendirian dan Pengelolaan Badan Usaha Milik Desa (BUMDES) di Desa Abiantuwung.}

Salah satu Desa yang termasuk dalam ciri khas, pendirian dan pengelolaan Badan Usaha Milik Desa yang telah diterangkan pada halaman sebelumnya, adalah Desa Abiantuwung, Kecamatan Kediri, Kabupaten Tabanan dimana desa ini merupakan desa yang sudah memiliki BUMDES dan telah berjalan mulai Tahun 2015. Pembentukan Badan Usaha Milik Desa (BUMDES) pada Desa Abiantuwung bertujuan sebagai pendorong pembangunan ekonomi tingkat desa. Pembangunan Ekonomi pada Desa Abiantuwung ini didasarkan keinginan desa untuk menjadikan masyarakatnya yang kreatif, inovatif, dan mampu meningkatkan keproduktivitas individu. Pembentukan masyarakat desa tersebut dilandasi oleh prinsip kooperatif, partisipatif, dan emansipatif masyarakat desa.

Desa Abiantuwung menjalankan BUMDES ini berpedoman pada Peraturan Daerah Kabupaten Tabanan Nomor 1 Tahun 2015 tentang Badan Usaha Milik Desa (BUMDES) yang mejadi acuan dalam pembentukan Badan Usaha Milik Desa yang ada di Kabupaten Tabanan. Pengelolaan BUMDES harus dikelola secara professional dan mandiri, begitupula dengan BUMDES Desa Abiantuwung menyeleksi orang-orang yang memiliki kompetensi untuk mengelolanya. Dilihat kenyataan perekrutan Pengelolaan BUMDES ini berlangsung selektif.

Menurut Kepala Desa Abiantuwung "Kami melakukan seleksi dan pemilihan untuk mengelola BUMDES kami agar tujuan yang diinginkan bia tercapai demi kesejahteraan masyarakat desa ini. Untuk Pengelola sendiri ada Ketua Bumdes Desa Abiantuwung, dibantu oleh 2 Ketua unit usaha BUMDES, dan karyawan" setelah itu kepala desa pun memberikan informasi bahwa "Ketua BUMDES kami berasal dari Pegawai BRI yang telah senior dan pensiunan, dan kebutulan ketua bumdes nya ini dulu bergerak pada bagian LPD desa ini, jadi kami tidak sembarang memilih pengelola BUMDES ini."

Sementara itu pada penyeleksi karyawan bumdes ini adalah dari mayarakat yang memiliki latar belakang yang desa ini menginginkan adalah minimal SMP. Ini diharapkan mereka harus mampu menyusun laporan aktivitas BUMDES yang berkaitan dengan dengan pekerjaannya. Contohnya pada Desa Abiantuwung Unit jasa Pertokoan dan Fotokopi, mereka harus menyusun laporan barang-barang yang terjual dan sisa barang ditoko atau fotokopian setiap periode tertentu (3 Bulanan atau 6 Bulanan sekali).

Pengelolaan BUMDES di Desa Abiantuwung ini juga melibatkan masyarakat untuk berperan aktif dalam pembangunan di desanya. Keterlibatan masyarakat ini dimulai dari perencanaan, pelaksanaan, hinggan pengelolaan dan evaluasi. Pengambilan keputusan dalam perencanaan pembanguna dilakukan dengan melibatkan stakeholder dalam masyarakat. Kepala Desa dan tokoh masyarakat desa Abiantuwung memegang peran penting untuk mendistribusikan ide, gagasan, manfaat pembangunan ini kepada warga sehingga muncul komitmen seluruh warga untuk terlibat dalam pengelolaan pembangunan sarana dan prasarana di Desa Abiantuwung. Partisipasi masyarakat saat pelaksanaan pembangunan infrastruktur sarana dan prasarana Desa Abiantuwung perenovasian bangunan di Desa tersebut melalui gotong royong di lingkungan RT mereka. Bentuk Partisipasi mayarakat setelah perenovasian sudah bisa nikmati dan dimanfaatkan.

\section{ii. Perkembangan dan Peningkatan Perekonomian Desa Abiantuwung dengan keberadaan Badan Usaha Milik Desa atau BUMDES}

Visi pembangunan yang mengutamakan manusia sangat relevan karena adanya pergeseran peranan pemerintah dalam konteks pembangunan, yang pada hakekatnya dilaksanakan oleh masyarakat. Sejak perencanaan hingga implementasi dan pemanfaatannya, peranan masyarakat yang menonjol. Peran itu lebih efektif apabila masyarakat yang menonjol. Peran itu lebih efektif apabila masyarakat juga berperan dalam penggunaan alokasi anggaran. Korten (1988:242-245) mengemukakan bahwa pembangunan itu sendiri haruslah merupakan suatu proses belajar, yaitu maksudnya peningkatan kemampuan masyarakat, baik individual maupun kolektif yang tidak hanya menyesuaikan diri pada perubahan, melainkan juga untuk mengarahkan perubahan itu sehingga sesuai dengan tujuannya sendiri. 
Teori diperlukan sebagai bingkai dalam melakukan penelitian. Dalam penelitian ini teori utama yang digunakan dengan topik Penganggaran Keuangan (dana desa) pada organisasi pemerintah desa. Untuk mendukung teori utama tersebut, riset ini turut mengacu pada tesis mengenai Desa dan Badan Usaha Milik Desa (BUMDES) yang didirikan di Desa Abiantuwung, Kecamatan Kediri, Kabupaten Tabanan.

Desa menurut UU Nomor 6 Tahun 2014 (UU Desa), definisi desa adalah desa dan desa adat atau yang disebut dengan nama lain, adalah kesatuan masyarakat hukum yang memiliki batas wilayah yang berwenang untuk mengatur dan mengurus urusan pemerintahan, kepentingan masyarakat setempat berdasarkan prakarsa masyarakat, hak asal usul, dan/atau hak tradisional yang diakui dan dihormati dalam sistem pemerintahan Negara Kesatuan Republik Indonesia (NKRI). Sebagai wakil negara, desa wajib melakukan pembangunan, baik pembangunan fisik maupun pembangunan sumber daya manusia, sebagai upaya peningkatan kualitas hidup dan kehidupan untuk sebesar-besarnya kesejahteraan masyarakat desa. Pembangunan desa yang berkelanjutan merupakan pembangunan desa yang tidak merusak lingkungan dan memberi hak kedaulatan untuk mengatur dirinya. Masyarakat desa harus berdaya agar pembangunan mencapai sasarannya. Maka yang diperlukan adalah upaya-upaya pemberdayaan masyarakat desa untuk membangun kemampuan masyarakat desa dengan cara mendorong, memotivasi, dan mengembangkan potensi sumber daya lokal yang dimiliki.

BUMDES merupakan lembaga usaha desa yang dikelola oleh masyarakat dan pemerintah desa dalam upaya memperkuat perekonomian desa dan dibentuk berdasarkan kebutuhan dan potensi desa. Pembentukan BUMDES didasarkan pada kebutuhan, potensi, dan kapasitas desa sebagai upaya peningkatan kesejahteraan masyarakat. Perencanaan dan pembentukan BUMDES adalah atas prakarsa masyarakat desa dan terdapat intervensi dari pemerintah desa. Pemerintah pusat hanya mendanai pembentukan BUMDES dan melakukan pengawasan. Keterlibatan pemerintah desa sebagai pendiri BUMDES bersama masyarakat atau pelaku kepentingan desa tersebut diharapkan mampu memenuhi Standar Pelayanan Minimal (SPM) yang diwujudkan dalam bentuk perlindungan atas intervensi yang merugikan dari pihak ketiga (baik dari dalam maupun luar desa). Pemerintah desa harus ikut berperan pada pembentukan BUMDES sebagai badan hukum yang berpijak pada tata aturan perundang-undangan yang berlaku, serta sesuai dengan kesepakatan yang terbangun di masyarakat desa.

BUMDES juga merupakan perwujudan partisipasi masyarakat desa secara keseluruhan, sehingga tidak menciptakan model usaha yang dikuasai oleh kelompok tertentu di tingkat desa. Artinya, tata aturan yang terwujud adalah mekanisme kelembagaan yang solid. Penguatan kapasitas kelembagaan akan mengarah pada adanya tata aturan yang mengikat seluruh anggota. Dengan adanya BUMDES diharapkan mampu meningkatkan pembangunan yang berdampak bagi peningkatan kesejahteraan masyarakat desa yang nantinya akan menjadi kesejahteraan nasional.

Desa Abiantuwung merupakan desa yang dipilih oleh pemerintah untuk diberikan berpeluang berkembang menjadi masyarakat desa yang kreatif, inovatif, dan produktif. Seluruh kebutuhan dana bagi pengembangan Desa Abiantuwung diperoleh dari kebutuhan Badan Usaha Milik Desa (BUMDES) Abiantuwung. Berjalannya waktu Desa Abiantuwung mulai mengalami perkembangan, oleh masyarakat, pembangunan daerah, dan tingkat produktif masyarakat meningkat. Untuk menjalankan hal tersebut Pemerintah Daerah AbianTuwung berpedoman pada Peraturan Daerah Kabupaten Tabanan Nomor 1 Tahun 2015 tentang Badan Usaha Milik Desa (BUMDES) yang menjadi acuan dalam pembentukan Badan Usaha Milik Desa yang ada di Tabanan.

Jauh sebelum adanya BUMDES di Desa Abiantuwung ini masyarakatnya masih sangat konsumtif. Masyarakat seakan bersaing satu sama lain untuk memenuhi keinginan dan gaya hidup yang seolah tidak ingin kalah antara yang satu dengan yang lainnya. Sehingga dengan kehidupan yang seperti itu semakin terlihat kesenjangan ekonomi yang semakin besar, karena kehidupan konsumtif yang tidak dibarengi dengan pendapatan yang memadai. Desa abian tuwung ini termasuk desa dengan ekonomi yang kurang stabil karena tidak ada perkembangan yang terlihat signifikan dari usaha-usaha yang didirikan. Selain itu kondisi 
masyarakat konsumtif yang tidak ada keinginan melakukan perubahan juga menjadi pemicu utama ketidak stabilan perekonomian masyarakat.

Dari sekian banyak masyarakat yang konsumtif tentunya ada segelintir masyarakat yang memiliki kesadaran dan ingin mengubah hidupnya. Tak sedikit juga dari mereka yang ingin mulai membangun usaha, akan tetapi pada saat itu hanya LPD yang menjadi tempat masyarakat dalam mengambil kredit. Seperti yang telah diketahui berdasarkan survei yang telah dilakukan bahwa bunga yang diberikan LPD untuk kredit lumayan besar sehingga masyarakat masih berpikir ulang untuk meminjam kredit sebagai modal usaha. Jadi, dapat disimpulkan bahwa sebelum adanya BUMDES di daerah Abiantuwung perekonomiannya tidak stabil karena masyarakat yang bersifat konsumtif yang belum memiliki keinginan untuk merubah gaya hidup mereka. Selain itu pemicu ketidakstabilan perekonomian di desa ini adalah keinginan masyarakat yang muncul akan tetapi terbentur dengan keadaan kredit yang mempunyai bunga lumayan tinggi.

Sehingga pembentukan BUMDES di Desa Abiantuwung ini memiliki tujuan utama untuk meningkatkan taraf hidup masyarakat miskin agar kesenjangan sosial di desa ini tidak bertambah besar, karena menurut survei yang telah dilakukan bahwa masih banyak jumlah KK di desa ini yang termasuk kategori masyarakat miskin yaitu sebesar $294 \mathrm{KK}$ dari total keseluruhan masyarakat abiantuwung yang berjumlah 2735 jiwa. Selain itu tujuan lain dari pembentukan BUMDES adalah untuk membentuk masyarakat yang produktif bukan masyarakat konsumtif yang menjadi gaya hidup masyarakat abian tuwung selama ini. Untuk mencapai tujuan tersebut banyak sekali hal yang telah dilakukan oleh pemerintah Desa Abiantuwung, salah satunya adalah dengan memberikan sosialisasi tentang kredit yang bersumber dari dana BUMDES untuk kredit produktif. Akan tetapi, pada kenyataannya sangatlah berbeda dengan apa yang diharapkan. Dengan adanya kredit produktif tersebut masyarakat malah memakai kredit tersebut untuk memenuhi gaya hidup konsumtif yang selama ini menjadi bagian hidup mereka, walaupun ada beberapa yang memang menggunakan kredit tersebut untuk ekonomi produktif yaitu dengan memanfaatkan dana kredit untuk membuka usaha. Sehingga sebelum di bangunnya BUMDES perekonomian di desa Abiatuwung kurang stabil untuk memenuhi kebutuhan hidup masyarkat di desa tersebut dan dengan jalan keluarnya pemerintah merencankan peningkatan taraf hidup di desa abiantuwung dengan mendirikannya BUMDES.

BUMDES Abiantuwung yang memiliki tujuan meningkatkan perekonomian desa telah mampu memberikan dampak yang sangat positif terhadap perekonomian desa Abiantuwung. Masyarakat desa Abiantuwung yang mayoritas merupakan masyarakat kelas kebawah mendapatkan kesempatan untuk mulai memutar roda perekonomian dengan adanya BUMDES di desa Abiantuwung itu sendiri. BUMDES yang merupakan program pemerintah untuk mengembangkan perekonomian terutama di perekonomian desa dapat mendorong perkembangan perekonomian desa dengan cara memberikan pinjaman dana bagi masyarakat kecil yang akan membuat usaha dengan bunga yang sangat minim. Bunga yang minim diterapkan dengan tujuan untuk mendorong masyarakat kelas kebawah tersebut untuk memulai usaha dan dapat meningkatkan taraf hidup masyarakat desa. Bunga minim juga diharapkan dapat meningkatkan laba bersih yang diperoleh masyarakat.

Berbagai usaha yang ditekuni masyarakat desa Abiantuwung sangat beragam, dari berjualan jajanan bali, sarana persembahan (Jejaitan), dan untuk yang sudah lebih maju dipakai untuk membeli bibit ternak babi untuk di pelihara atau bahkan sudah ada untuk di perjual belikan.masyarakat yang menjual jajan bali sangat terbantu dengan adanya bumdes di Abiantuwung tersebut. Orang- orang yang memiliki kemampuan membuat jajan bali yang beraneka ragam namun memiliki kendala di modal sangat dibantu dengan adanya BUMDES di desa tersebut. Masyarakat yang biasa menjual jajan bali yang hanya 2 jenis, mereka dapat mengembangkan usaha mereka menjadi menjual jajan bali yang beraneka ragam, hingga 7 jenis.

Ini sangat berdampak positif bagi pendapatan yang diterima oleh para penjual jajan bali tersebut, bahkan ada salah satu warga yang sudah mengembalikan uang pinjaman dari BUMDES dan mengelola usaha jajan balinya dengan modal dari pendapatan yang diterima dari pengelolaan dana bumdes tersebut. Bali yang terkenal dengan upakara/ upacara 
yadnyanya dimanfaatkan oleh masyarakat di desa abiantuwung itu sendiri. Masyarakat yang memiliki kemahiran dan kemampuan membuat sarana dan prasarana untuk upacara yadnya tersebut meminjam uang di BUMDES dengan bunga yang sangat minim dan memulai usaha menjual sarana dan prasarana untuk upacara/ upakara yadnya tersebut. Karena kebutuhan akan sarana dan prasarana yang cukup tinggi maka banyak masyarakat yang memiliki usaha yang sama yaitu menjual sarana dan prasarana upacara/upakara yadnya tersebut dengan meminjam uang di BUMDES desa Abiantuwung tersebut.

Mereka meminjam uang di bumdes di karenakan bunga yang dikenakan atas pinjaman tersebut sangat minim dibandingkan dengan LPD di desa itu sendiri. Namun dana yang dipinjam tentunya tidak akan sebesar dana yang bisa di peroleh ketika meminjam di LPD. Bagi sebagian masyarakat yang mampu membaca peluang bisnis. Mereka meminjam dana di bumdes dan melakukan usaha jual beli bibit ternak babi. Bisnis ini dipilih oleh masyarakat karena di daerah tabanan pada umumnya dan desa Abiantuwung pada khususnya banyak masyarakat yang memilih beternak babi karena hasil yang didapat relatif cepat dan menguntungkan. Beternak babi juga didorong dengan pakan ternak badi relatif mudah di dapat di desa abian tuwung tersebut. Bahkan tanpa perlu membeli masyarakat yang memilih untuk beternak babi memberi pakan ternak mereka dengan (dag-dag). Dag-dag merupakan paka yang dibuat dari batang dan daun talas yang dipotong-potong kemudian direbus. Berdasarkan hal tersebut maka sebagian masyarakat desa abian tuwung memilih untuk beternak babi dan dimanfaatkan oleh masyarakat yang meminjam uang di bumdes untuk melakukan usaha jual beli bibit ternak babi.

Sekarang BUMDES desa Abiantuwung berencana untuk membuat toko GROSIR dengan alasan di desa Abiantuwung sendiri terdapat banyak sekali warung-warung atau toko kecil agar nantinya warung-warung dan toko kecil tersebut dapat mengambil barang dagangan di toko grosir yang akan dibuat oleh BUMDES tersebut sehingga itu akan menambah pendapatan BUMDES dan mempermudah masyarakat yang membuka warungwarung/ toko kecil tersebut dalam memperoleh barang dagangannya. Setelah diterapkannya BUMDES di Desa Abiantuwung dan melihat partisipasi masyarakat yang begitu tinggi, banyak dampak yang diberikan kepala desa dan masyarakat desa. Pembangunan di desa semakin meningkat. BUMDES di Desa Abiantuwung ini dinilai sudah berhasil dijalankan meskipun belum semua unit berjalan efektif. Keberhasilan ini tentunya tidak luput dari kerja keras dan partisipasi seluruh masyarakat desa. Dengan memanfaatkan BUMDES, kondisi masyarakatyang dulunya dikatakan "Kurang Mampu" sekarang kehidupannya lebih terjamin, kesejahteraan meningkat, pengangguran berkurang, dan banyak pembangunan yang dilakukan berorientasi pada masyarakat.

Suatu kebijakan akan menimbulkan suatu dampak. Dampak kebijakan public merupakan sebuah studi evaluasi terhadap suatu kebijakan pemerintah yang sudah diimplementasikan kepada sasaran kebijakan. Untuk mengetahui dampak perlu adanya evaluasi. Evaluasi dampak dalam penelitian ini menggunakan jenis studi evaluasi yang dikemukakan oleh Finsterbuch dan Motz (dalam wibawa, 1994:74) yaitu menggunakan single program before after. Dimana evaluator hanya menggunakan kelompok eksperimen yaitu kelompok yang dikenai kebijakan untuk memperoleh data dari evaluasi dampak kebijakan ini. Kelompok yang dikenai kebijakan disini adalah masyarakat desa Abiantuwung. Dalam menggunakan jenis evaluasi single program before after ini untuk memperoleh data mengenai keadaaan masyarakat sebelum dan setelah adanya BUMDES.

\section{Simpulan dan Saran}

Berdasarkan pemaparan diatas, simpulan yang didapat sebagai berikut.

a. BUMDES Desa Abiantuwung telah berhasil memberi dampak yang positif bagi peningkatan perekonomian desa dan kesejahteraan masyaraka, BUMDES Desa Abiantuwung yang berdampak terhadap tingkat masyarakat konsumtif ini, semakin berkurang, dan masyarakat produktif mulai meningkat. Pengangguran pada desa Abiantuwung ikut berkurang karena masyarakat yang mulai kreatif untuk membuat taraf hidupnya menjadi lebih baik dengan usaha-usaha kecil yang masyarakat desa 
setempat dirikan. Pembangunan desa pun semakin lancer dengan adanya dana yang dihasilkan dari BUMDES.

b. Pengelolaan Desa Abiantuwung pada BUMDES sangat tertata dengan berpacu pada peraturan yang sudah ditetapkan oleh Pemerintah. Pengelolaan BUMDES ini dilihat dari pengurus BUMDES, yang sebelumnya di seleksi dan memilih secara ketat orang yang bisa mengelola BUMDES ini dengan baik dan mampu mengubah pemikiran masyarakat desa setempat.

c. BUMDES Desa Abiantuwung walaupun belum maksimal dalam menjalankan unit-unit usahanya. Dari keempat unit BUMDES baru dua yang telah berjalan dengan efektif, usaha tersebut adalah simpan pinjam, dan usaha kecil seperti berdagang jajan bali, pembuatan upakara, dan pembuatan bibit babi. Hal tersebut disebabkan karena sumber daya manusia yang belum mahir dalam mengolah unit-unit tersebut tetapi adanya tingkat partisipasi masyarakat yang begitu tinggi terhadap kegiatan BUMDES yang sudah berjalan membuat BUMDES Desa Abiantuwung.

Berdasarkan pemaparan diatas, saran yang dapat diberikan adalah bagi pemerintah desa dan pengelola BUMDES supaya segera lebih efektif dalam menjalankan unitunit usaha lain agar tujuan BUMDES memaksimalkan kesejahteraan masyarakat desa setempat serta bagi pemerintah pusat supaya lebih melakukan mengawas kepada berjalannya BUMDES Desa setempat secara efektif, agar dikemudian hari apabila BUMDES terjadi permasalahan bisa teratasi dan menemukan jalan supaya lancar kembali. Pemerintah juga bisa melihat dampak dari pendirian ini yang tetap mengacu pada kesejahteraan masyarakat desa. Karena Kebijakan yang seperti inilah yang harus diterapkan pada tingkat desa.

\section{DAFTAR PUSTAKA}

Hamzah, Ardi, SE, MSi, Ak, CA, AAP-B.2015.Tata Kelola Pemerintahan Desa.Surabaya.Pustaka

www.balipos.com

Surya Dharma, Pinondang Simanjuntak.2002. Paradigma Birokrasi Pemerintahdan Otonomi Daerah. Jurnal Bisnis dan Birokrasi

Subarsono, AG.2006.Analisis Kebijakan Publik: Teori dan Aplikasi.Yogyakarta:Pustaka pelajar

Hayami, Y dan Kikuchi, M.1987. Dilema Ekonomi Desa, Suatu Pendekatan Ekonomi Terhadap Perubahan Kelembagaan Di Asia. Jakarta: Yayasan Obor Indonesia 